\title{
INFLUENCE OF LOCAL INFILTRATION ANALGESIA ON POSTOPERATIVE PAIN IN ABDOMINOPLASTY PATIENTS
}

\author{
Dinko Bagatin $^{1,3}$,Tomica Bagatin ${ }^{1,3}$, Johann Nemrava $^{1,3}$, Martina Šarec Ivelj ${ }^{1}$,

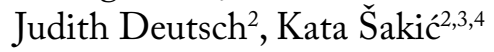 \\ ${ }^{1}$ Department of General, Plastic, Reconstuctive and Aesthetic Surgery at Maxillofacial, General, \\ Plastic, Reconstructive and Aesthetic Surgery Polyclinic “Bagatin”, Zagreb, Croatia; \\ ${ }^{2}$ Department of Anaesthesiology and Pain therapy at Maxillofacial, General, \\ Plastic, Reconstructive and Aesthetic Surgery Polyclinic “Bagatin”, Zagreb, Croatia; \\ ${ }^{3}$ Faculty of Dental medicine and Health Osijek, Josip Juraj Strossmayer University in Osijek, Osijek, Croatia; \\ ${ }^{4}$ Catholic University of Croatia, Zagreb, Croatia
}

\begin{abstract}
SUMMARY - The aim of this study was the influence of local infiltrating analgesia with levobupivacaine on acute postoperative pain in patients that underwent abdominoplasty in day surgery. Local infiltration anesthesia is an injection of local anesthetic solution in painful areas. General anesthesia and tumescent fluid solution were performed in all patients.

The study included 55 patients within age range from 20 to 72 years old. Study was conducted from January 2016 to February 2019.Postoperative pain after abdominoplasty was evaluated.

LIA were performed before closure of abdominal wall after resection of skin and subcutaneous fat in lower part of abdominal wall. Infiltration was performed after plication of rectus abdominis muscles with single shot of $40 \mathrm{ml} 0.25 \%$ Bupivacaine.

Postoperative pain was reduced in the abdominal wall and in the wound area around umbilicus and in lower abdomen scar after waking from general anesthesia. Occurrence of acute postoperative was noticed in all participants. $85 \%$ of patients required an additional dose of analgesics and only in $3 \%$ of patients was required during the first postoperative day discharged during 48 hours.

The research has shown that the appearance of acute postoperative pain did not lead to prolonged stay in the facility for day surgery.
\end{abstract}

Key words: local infiltration analgesia (LLA), abdominal wall, low pain, faster recovery.

\section{Introduction}

Abdominoplasty was the $3^{\text {rd }}$ most performed cosmetic surgery procedure in Brazil in 2008.It was the $5^{\text {th }}$ most performed cosmetic surgery procedure in the USA in the same year. 34 patients underwent abdominoplasty in "Bagatin" Polyclinic during 2018. It was $4^{\text {th }}$ most popular procedure after liposuction, breast sur-

Correspondence to: Dinko Bagatin, $M D, P h D$, Department of General and Plastic Surgery at Maxillofacial, General and Plastic Surgery Polyclinic “Bagatin”, Zagreb, Croatia

E-mail:dinko.bagatin@bagatin.hr gery and rhinoplasty procedures and its popularity rises each year. The reasons for its rise are the limitations of liposuction procedures. Pain is a good quality predictor of surgical care for patients ${ }^{1-5}$. Many publications analyze this problem with severe pain in $40-50 \%$ of patients. Abdominoplasty is one of the most painful surgical procedures in aesthetic surgery ${ }^{6}$. The main reasons are the large surgical field, need for usually extensive mobilization of tissue, plication of straight abdominal muscles for deformities of myoaponeurotic layer and extensive liposuction. Every part of surgical procedure provides great pain intensity so 


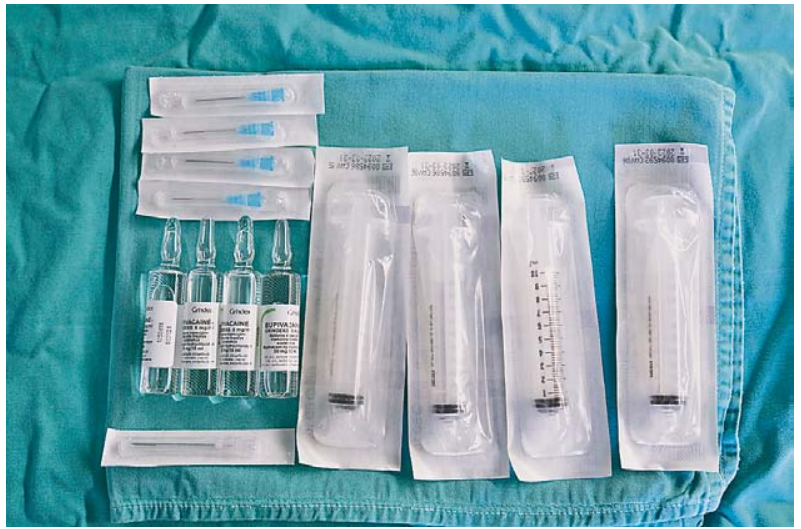

Figure 1. Local anaesthetic preparation kit for abdominoplasty procedure.

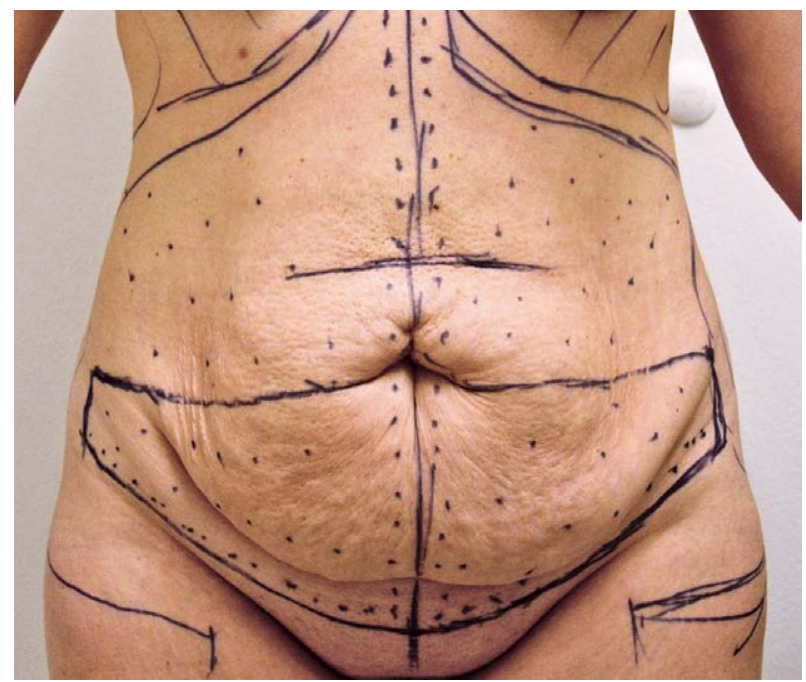

Figure 2. Landmarks for local infltration anaesthesia and skin incision before abdominoplasty procedure.

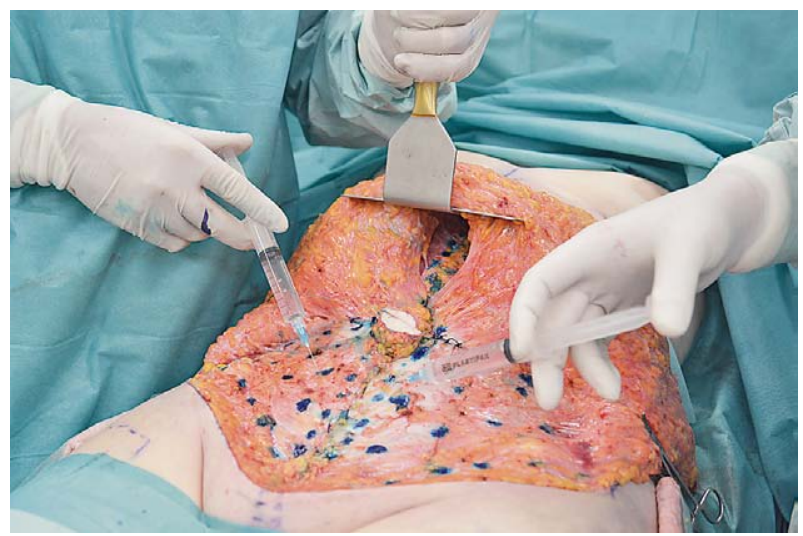

Figure 3. Multiple infiltrations of bupivacaine in the level of the abdominal wall muscles during abdominoplasty procedure.

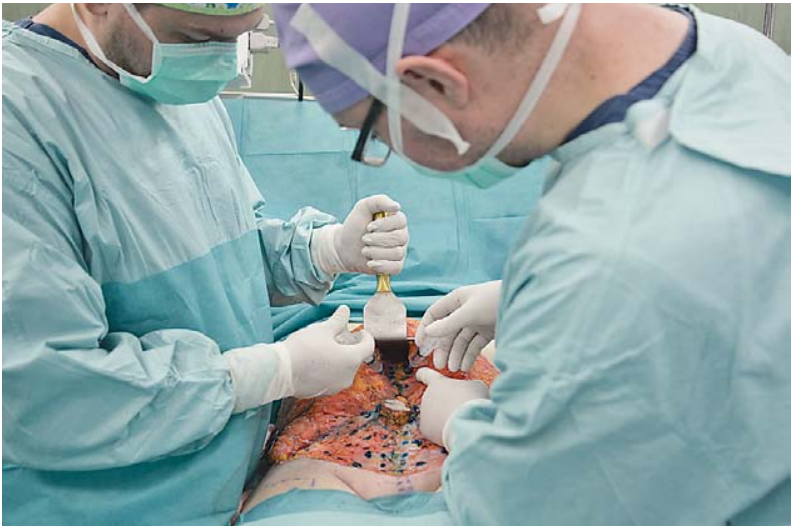

Figure 4. Application of bupivacaine in the xiphoid region.

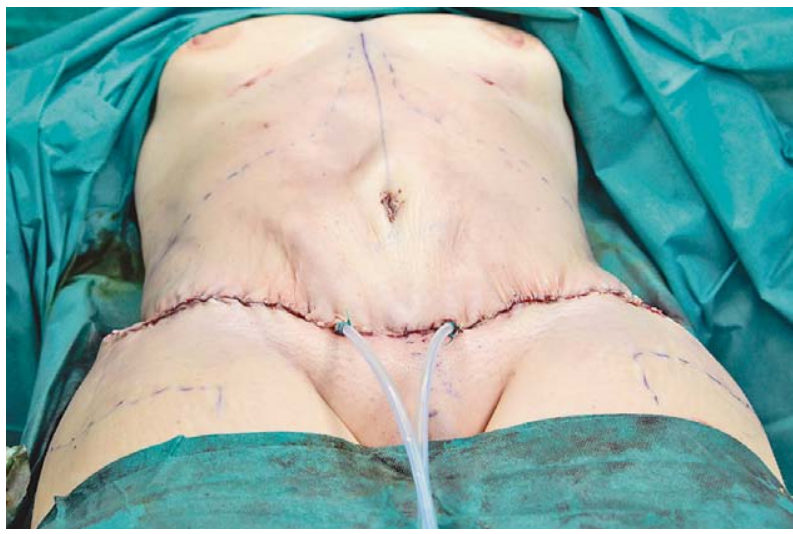

Figure 5. Patient at the end of abdominoplasty procedure with drainage systems.

reducing postoperative pain and enhancing recovery is necessary. Local anesthetics for infiltration usually utilized are levobupivacaine or bupivacaine for their long lasting effect ${ }^{7}$. Purpose of the article is to provide practical advice on how to reduce postoperative pain performing local infiltration analgesia (LIA) with bupivacaine in patients undergoing abdominoplasty. Patients have been operated in general anesthesia and have had initial infiltration of the superficial and deep subcutaneous fat and connective tissue with tumescent fluid solution.

\section{Methods}

The study included 55 patients who underwent abdominoplasty procedure. Patients were between 20 and 72 years of age and out of 55 patients, 5 were male and 50 were female patients. It is a procedure that con- 
tains several stages: first VASER liposuction is performed in front and in lateral part of lower chest and superficial abdominal wall above muscle superficial fascia, afterwards a very low linear incision in the lower parts of abdominal wall and urogenital region is exercised, following the mobilization of the skin and cutaneous tissue in the upper position and laterally to rib cage and in the lower part, almost to the back parts to the posterior axillar line in abdominal wall region. At the same time umbilicus is freed from cutaneous and fat tissue which is then mobilized. Subsequently, follows the plication of the rectus abdominis muscles. Skin and subcutaneous tissue are removed from umbilicus down to lower part of the abdominal wall region and transition of $1 / 3$ to second $1 / 3$ of urogenital region. Urogenital region is advanced in the upper position and fixed in that position with sutures. During that period the tissue is washed using $0.9 \% \mathrm{NaCl}$ and Betadine solution. Extensive infiltration of abdominal wall from xiphoid process to urogenital region and laterally to anterior axillary line follows. The first region of the plication is medially from xiphoid process to urogenital region and afterwards the lower wound and then the region of external oblique muscle on both sides. Single shot infiltration is performed with bupivacaine in the level of the abdominal wall muscles. Infiltration is performed in 40 to 50 injection sites. Four $10 \mathrm{ml}$ syringes are used and the application is performed with 23 gauge needles (Fig1-5).

Patients were nonsmokers, and even if they smoked they were obligated to stop smoking 4 to 6 weeks before operation. Prior to surgical procedure, two patients had alterations in blood tests: one had anemia for lack of iron and the other had von Wilebrandt disease Type I. In both cases patients were preoperatively prepared and examined and both needed adequate prescribed therapy preoperatively and postoperatively.

Duration of the surgical procedure varied from 4 to 8 hours, 6 hours approximate. General oral endotracheal anesthesia was performed. $1000 \mathrm{ml} 0.9 \% \mathrm{NaCl}$, lidocaine $2 \% 50 \mathrm{ml}$ and $\mathrm{NaHCO}_{3}$ (1- mol. solution) $10 \mathrm{ml}$ were used for liposuction tumescent fluid. For local infiltration analgesia (LIA) of abdominal wall 40 $\mathrm{ml}$ of bupivacaine were used.

The statistics data are shown in tables and figures, variables that were normally distributed, were tested by Kolmogorov-Smirnov test. Categorical variables were shown by using absolute frequencies and ratios, quantitative variables were expressed as median scores and interquartile ranges. The data for descriptive variables were analyzed by chi-square test, though differences in quantitative variables were tested by MannWhitney U test. Particular clinical parameters were evaluated by Spearman's correlation analysis. $\mathrm{P}<0.05$ was considered to be statistically significant. Statistical analysis was performed by the IBM SPSS Statistics for Windows 23.

\section{Results}

The study included 55 patients who underwent abdominoplasty procedure. Patients were between 20 and 72 years of age and out of 55 patients, 5 were male and 50 were female patients. $40 \%$ of patients were under the age of 40 and $60 \%$ were above the age of 40 years. Patients median weight was 76.5 kilograms, median height was $168.50 \mathrm{~cm}$ and median BMI was 26.85 varied from normal 23.62, overweight to obese 30.37. In postoperative setting immediately after surgery, patients felt low incidence of pain in the treated region. Occurrence of acute postoperative was noticed in all participants. $85 \%$ of patients required anadditional dose of analgesics and only in $3 \%$ of patients it was required during the first postoperative day. During the first post-operative day, an additional dose of analgesics was provided only to $3 \%$ of patients and they were discharged from the facility.

Table 1. Presentation of participants considering age, surgery duration and body weight

\begin{tabular}{|l|l|l|}
\hline \multicolumn{2}{|l|}{} & $\begin{array}{l}\text { Number (\%) } \\
\text { of patients }\end{array}$ \\
\hline Age (years) & $20-39$ & $36(63.33)$ \\
& $\geq 40$ & $19(36.67)$ \\
& Sum & $55(100.00)$ \\
\hline $\begin{array}{l}\text { Surgery duration } \\
\text { (hours) }\end{array}$ & $0-3,99$ & $11(21.67)$ \\
& $>4$ & $44(78.33)$ \\
& Sum & $55(100.00)$ \\
\hline BMI categories & Underweight $(<20)$ & $3(6.67)$ \\
& Normal BW (20-25) & $32(56.67)$ \\
& Overweight BW & $13(23.33)$ \\
& $(25-30)$ & $7(13.33)$ \\
& Obesity (>30) & $55(100.00)$ \\
\hline
\end{tabular}

BMI-body mass index, BW - body weight 
Table 2. Comparison of premedication and postoperative vomiting

\begin{tabular}{|l|l|l|l|l|}
\hline \multirow{2}{*}{} & \multicolumn{2}{|l|}{ Number (\%) of patients } & \multirow{2}{*}{ P $^{*}$} \\
\cline { 2 - 4 } & Vomiting & No vomiting & Total & \\
\hline Antiemetic drug preoperatively & $7(80.0)$ & $14(32.0)$ & $22(40.0)$ & \multirow{2}{*}{0.01} \\
\hline No antiemetic drug preoperatively & $2(20.0)$ & $32(68.0)$ & $33(60.0)$ & \\
\hline Total & $9(100.0)$ & $46(100.0)$ & $55(100.0)$ & \\
\hline
\end{tabular}

The obtained results showed ASA I status in $68.33 \%$ of cases. Hematocrit and hemoglobin levels were significantly higher in male patients.

Presentation of participants considering age, surgery duration and body weight (Table 1).

The patients for longer surgical procedures received prophylactic antiemetic drugs Setronon (88.9\%) and Reglan (80.0\%). Postoperative nausea and vomiting were recorded exclusively amongst the female patients (Table 2).

Measuring vital functions reduces the frequency of unwanted events and postoperative complications. In day surgery, the need for urgent interventions and switching to intensive care units has been reduced. Educations of The Rapid Response System teaches nurses about the importance of rapid reaction.

Patients were mobilized in few hours after surgery and returned in vertical position one week after the procedure. They were more active and have had a high quality of postoperative recovery. All of their functions were regained in few days and their appetite was normal or even better almost immediately after operation. The drains in the front are the only reason patients stay mostly at home in the first days after surgery as they are inconvenient to go around with. The recommendation for first postoperative week was to walk in semi flexed position and lie in upright position with legs bend in knees. Every patient received low molecular heparin for 10 days after surgery until full mobilization. Every patient could return to work after 2 weeks, but the recommendation for the safety reasons was not to work for one month, especially if their job was hard physical work. The participants could have managed harder activities 3 to 4 weeks after surgical procedure. Patients' feedback was that their recovery was beyond expectation and every patient was satisfied with their decision to undergo this surgical procedure because their function and aesthetics were much improved. Local infiltration analgesia (LIA) is a necessary addition to every abdominoplasty patient for it makes sig- nificantly faster and easier recovery for patients who can stand up and take care of themselves practically immediately, despite large extent of this surgical procedure. This helps the patient and the surgeon get optimal results and satisfied patients.

All patients who underwent abdominoplasty were discharged from the Polyclinic during 48 hours, while the patients who underwent other type surgery like mammoplasty, rhinoplasty or other, were discharged on the same day of the surgery.

\section{Discussion}

Most of the patients in day surgery were ASA status I, which suggests they were young and healthy. The preoperative assessment confirmed patients who underwent surgical procedure in general anesthesia experienced nausea and vomiting, especially women of increased body weight and with longer procedures as abdominoplasty, as published in literature ${ }^{8-11}$. The intensity of postoperative pain is not forceful after abdominoplasty with LIA. Many studies published data involving local infiltration analgesia in the abdominal wall, but with different long lasting anesthetics and in different dosage ${ }^{6-9}$ while comparisons have been made between different local anesthetics and application was just in rectus sheet or wound or nerve blocks were used. However, application of this amount of local anesthetic (Bupivacaine) in entire abdominal wall and abdominoplasty wound has not been analyzed yet. General endotracheal anesthesia is performed for abdominoplasty procedure in this study, tumescent infiltration for liposuction in specific dosage and $40 \mathrm{ml}$ of Bupivacaine for infiltration of abdominal wall and wound area. Tumescent solution has analgesic peak after 8 to 12 hours and it loses its analgesic quality in total after 48 hours. With inclusion of local infiltration analgesia in rectus abdominis, externus oblique muscles, inguinal region and wound area in one section immediately before the closing, wound pain was re- 
duced in the early postoperative period, but the effect of infiltrated tumescent fluid cannot be excluded ${ }^{12,13}$. Our experience in local infiltration analgesia and analysis and talking with our patients after each surgical procedure gives us proof this Bupivacaine infiltration is useful and pain is reduced in first postoperative days compared with our patients from the past who did not receive this type of local infiltration analgesia. This is the reason we must make a larger study with more precise analysis and more defined parameters to scientifically prove that our method really works.

\section{Conclusions}

By choosing to apply a combination of local infiltration analgesia (LIA), with general anesthesia in individuals who undergo an abdominoplastic liposuction, taking into consideration a number of applied analgesics, the intensity of postoperative pain is not forceful. Postoperative complications, acute pain, nausea and vomiting are not frequent and are not intense, meaning that after abdominoplasty with LIA they do not prolong the stay of patients in day surgery

\section{Acknowledgements}

The authors thank the Medical Staff of "Bagatin" Polyclinic and the students (Farah Al-Khazae, Matea Sarka, Ema Šaić and Marijana Grden) of Faculty of Dental Medicine and Health Osijek for their support and assistance

\section{References}

1. Kakagia DD, Fotiadis S, Tripsiannis G, et al. Postoperative Analgesic effect of locally Infiltrated Levobupivacaine in Fleurde-Lys Abdominoplasty. Aesth Plast Surg. 2007;31(2):128132, 2007. https://doi.org/10.1007/s00266-006-0187-4
2. Rawal N. Current issues in postoperative pain management. Eur J Anaesthesiol. 2016;33:160-71. https.//doi.org/10.1097/ EJA.0000000000000366

3. Chauvin M. State of the art of pain treatment following ambulatory surgery. Eur J Anaesthesiol Suppl. 2003;28:3-6.

4. McGrath B, Elgendy H, Chung F, et al. Thirty percent of patients have moderate to severe pain $24 \mathrm{hr}$ after ambulatory surgery: a survey of 5,703 patients. Can J Anaesth. 2004;51: 886-91. htpps://doi.org/10.1007/BF03018885

5. Klein SM, Buckenmaier CC, III. Ambulatory surgery with long acting regional anesthesia. Minerva Anestesiol 2002;68: 833-41.

6. Abo-Zeid MA, A1-Refaey AK, Zeina AM. Surgically-assisted abdominal wall blocks for analgesia after abdominoplasty: A prospective randomized trial. Saudi J Anaesth. 2018;12(4): 593-598. htpps://doi.org/10.4103/sja.SJA_303_18

7. Mohamed AA, Safan TF, Hamed HF, et al. Tumescent Local Infiltration Anesthesia for Mini Abdominoplasty with Liposuction. Maced J Med Sci. 2018;19;6(11):2073-2078. https:// doi.org/10.3889/oamjms.2018.475

8. Tjeertes EK, Hoeks SE, Beks SB, et al. Obesity-a risk factor for postoperative complications in general surgery? BMC Anesthesiol. 2015;15:112. https://doi.org/10.1186/s12871-015-0096-7

9. Varun VD, Milind SW. Unfavourable outcomes of liposuction and their management. Indian J Plast Surg. 2013; 46(2): 377392. https://doi.org/10.4103/0970-0358.118617

10. Šakić K. Organizing the acute pain service in Croatia - How to start? Liječ Vjesn 2005; 127; (Supl.2) 67-72.

11. Rawal N, Axelsson K, Hylander J, et al. Postoperative patientcontrolled local anesthetic administration at home. Anesth Analg. 1998;86:86-9.

12. Moiniche S, Jorgensen H, Wetterslev J, et al. Local anesthetic infiltration for postoperative pain relief after laparoscopy: a qualitative and quantitative systematic review of intraperitoneal, port-site infiltration and mesosalpinx block. Anesth Analg. 2000;90:899-912.

13. Fredman B, Zohar E, Tarabykin A, et al. Bupivacaine wound instillation via an electronic patient-controlled analgesia device and a double-catheter system does not decrease postoperative pain or opioid requirements after major abdominal surgery. Anesth Analg. 2001;92:189-93. 


\title{
Sažetak
}

\section{UTJECAJ LOKALNE INFILTRACIJSKE ANALGEZIJE NA POSLIJEOPERACIJSKU BOL U PACIJENATA S ABDOMINOPLASTIKOM}

\author{
D. Bagatin, T Bagatin, J. Nemrava, M. Šarec Ivelj, J. Deutsch i K. Šakić
}

Cilj istraživanja je utjecaj lokalne infiltracijske analgezije s levobupivakainom na akutnu postoperacijsku bol u pacijenata podvrgnutih abdominoplastici u dnevnoj kirurgiji. Lokalna infiltracijska anestezija je injiciranje lokalnog anestetika u bolna područja na kojima operiramo. Opća anestezija učinjena je uz infiltraciju trbušnog potkožnog zida s tumescentnom otopinom.

U studiju je uključeno 55 pacijenta u dobi od 20 do 72 godine. Studija se provodila od siječnja 2016. do velječe 2019. godine s evaluacijom poslijeoperacijske boli kod abdominoplastike. LIA se koristila prije zatvaranja trbušne stjenke nakon resekcije kožno-potkožnog tkiva u području donjeg dijela trbušne stjenke sa $40 \mathrm{ml}$ 0,5 \% Bupivakaina

Poslijeoperacijska bolu trbušnom zidu i u rani oko pupka i u području donjeg vodoravnog reza bila je manja.Dodatne analgetike poslije kirurškog zahvata dobilo je $85 \%$ pacijenata dok prvi poslijeoperacijski dan samo $3 \%$ pacijenata koji su otpušteni iz Poliklinike tijekom 48 sati.

Istraživanje pokazuje da poslijeoperacijska bol poslije abdominoplastike neće produljiti boravak u poliklinici.

Ključne rječi: lokalna infiltracijska analgezija (LIA), trbušni zid, niska bol, brži oporavk. 